REGARDS

SUR L'ECONOMIE ALLEMANDE

BULLETIN ECONOMIQUE DU CRAC

\section{Regards sur l'économie allemande}

Bulletin économique du CIRAC

$90 \mid 2009$

Varia

\title{
Réformes structurelles
}

Fünf Jahre Agenda 2010

\section{CpenEdition}

\section{Journals}

Édition électronique

URL : http://journals.openedition.org/rea/3606

DOI : $10.4000 /$ rea.3606

ISBN : 978-2-8218-0876-8

ISSN : 1965-0787

Éditeur

CIRAC

Édition imprimée

Date de publication : 1 mars 2009

ISSN : 1156-8992

Référence électronique

"Réformes structurelles », Regards sur l'économie allemande [En ligne], 90 | mars 2009, mis en ligne le 25 mars 2009, consulté le 22 septembre 2020. URL : http://journals.openedition.org/rea/3606 ; DOI : https://doi.org/10.4000/rea.3606

Ce document a été généré automatiquement le 22 septembre 2020

(C) CIRAC 


\section{Réformes structurelles}

Fünf Jahre Agenda 2010

\section{RÉFÉRENCE}

Fünf Jahre Agenda 2010, Vierteljahrshefte zur Wirtschaftsforschung, n 1, 2008, DIW, Berlin, $136 \mathrm{p}$.

1 Ironie de l'histoire, la crise économique que nous traversons confère un degré d'actualité tout particulier à ce bilan de l'Agenda 2010 publié par l'institut DIW de Berlin. Des experts de renom (dont W. Eichhorst dont nous publions dans ce numéro une analyse des effets stabilisateurs du chômage partiel) passent en revue, tout en en évaluant l'impact, les principaux axes de ce programme de réformes structurelles lancé par le gouvernement Schröder en mars 2003, c'est-à-dire au plus fort de la dernière crise économique. Un programme qui a permis à l'Allemagne de commencer à s'adapter aux changements structurels qui se font jour depuis les années 1990 et que poursuit le gouvernement Merkel. On peut en tirer deux constats. Le premier: les réformes de fond ne peuvent se faire que dans la continuité. Le second: une crise force à affronter le réel et, ce faisant, aiguise la conscience de la nécessité d'un changement. Encore fautil l'assumer... (ib) 